\title{
RESOURCE EXTRACTION IN A NEWLY CONQUERED PROVINCE: OTTOMAN SYRIA IN THE MID-SIXTEENTH CENTURY
}

\section{Linda T. Darling}

University of Arizona

\section{ABSTRACT}

This paper examines Ottoman governance in Syria in the decades after its conquest through the mühimme defterleri (registers of "important affairs") from 1544 to 1572. It catalogues the issues addressed in these registers and discusses how the Ottoman state dealt with them. Studies of tax registers produce the impression that the Ottoman Empire's relationship to its provinces was one of unmitigated exploitation, but other kinds of sources can be expected to reveal different aspects of Ottoman provincial administration. The issues addressed by the orders in these registers fall into three broad categories: money (including taxes and their collection, arrears, fiscal oppression, expenditures, and money transfers); men, that is, the military (timar-holders, Janissaries, the Yemen and Cyprus campaigns); and administration (appointments, promotions, registers, inspections). They provide a view of resource extraction from the provinces more complex than mere exploitation.

Honoring Nenad Moačanin would appear to demand a focus on the Balkans, but this paper instead deals with Syria, newly conquered in 1516. It contributes to the goal of eventually bringing together the provinces of the Ottoman Empire in a comparative framework to highlight the similarities and differences within this multinational empire. Syria's comparability with the Balkan provinces is not initially obvious, but long after its conquest, administrators still considered it a frontier province. ${ }^{1}$ Studies of taxation registers paint the Empire's relationship to its provinces as one of sheer exploitation, but other sources reveal different aspects of Ottoman provincial administration. This paper examines Ottoman governance in Syria in the decades after the conquest through the lens of the mühimme defterleri (registers of "important affairs") from the years 1544 to $1572 .^{2}$ It catalogues the

Kathryn A. Ebel, "Representations of the Frontier in Ottoman Town Views of the Sixteenth Century," Imago Mundi 60.1 (2008): 9.

2 Topkapı Sarayı Arşivi H.951-952 Taribli ve E-12321 Numaralı Mübimme Defteri, ed. Halil Sahillioğlu (Istanbul: IRCICA, 2002), hereafter E-12321 Numaralı Mühimme Defteri; 3 Numaralı Mühimme Defteri (966-968/1558-1560), Özet ve Transkripsiyon (Ankara: T.C. Başbakanlık Devlet Arşivleri Genel Müdürlüğü, Osmanlı Arşivi Daire Bakanlığı, 1993); 5 Numaralı Mübimme Defteri (973/1565-1566), Özet ve Indeks (Ankara: T.C. Başbakanlık Devlet Arşivleri Genel Müdürlügü, Osmanlı Arşivi Daire Bakanlığı, 1994); 6 Numaralı Mühimme 
issues addressed in these registers and discusses how the Ottoman state dealt with them. The mübimme registers refer frequently to the administration of the Syrian provinces (for much of the sixteenth century these were Şam/Damascus, Haleb/ Aleppo, and Trablus/Tripoli). ${ }^{3}$ The issues generating the orders in these registers fall into three broad categories: money (including taxation, arrears, fiscal oppression, expenditures, and money transfers); men, that is, the military (timar-holders, Janissaries, the Yemen and Cyprus campaigns), and administration (appointments, promotions, registers, inspections). They provide a view of resource extraction from the provinces that proves more complex than mere exploitation.

No records on Syria exist from immediately after the conquest. Within a decade or so, however, tahrir survey registers begin to appear, as well as legal court records (kadi sicilleri) and waqf documents. These records provide data on the region's population, production, revenue, and waqf establishment and operation. ${ }^{4}$ The general consensus of scholars is that Syria prospered after becoming part of the Ottoman Empire; population and production grew, and the opening of borders to the north and east enhanced commerce and urbanization. ${ }^{5}$ Increased wealth was thus available to satisfy any increases in exploitation.

Ottoman chronicles, on the other hand, represented Syria primarily as a site for the appointment and recruitment of soldiers and administrators. In the period from 1560 to 1640 covered by Selaniki, Peçevi, and Solakzade, the provinces of

Defteri (972/1564-1565), Özet - Transkripsiyon ve İndeks (Ankara: T.C. Başbakanlık Devlet Arşivleri Genel Müdürlügüu, Osmanlı Arşivi Daire Bakanlığı, 1995); 7 Numaralı Mühimme Defteri (975-976/1567-1569), Özet - Transkripsiyon - Indeks (Ankara: T.C. Başbakanlık Devlet Arşivleri Genel Müdürlügü, Osmanlı Arşivi Daire Bakanlığı, 1998); 12 Numaralı Mühimme Defteri (978-979/1570-1572), Özet - Transkripsiyon ve İndeks (Ankara: T.C. Başbakanlık Devlet Arşivleri Genel Müdürlüğü, Osmanlı Arşivi Daire Bakanlığı, 1998). Register entries are cited by register number and entry number.

3 This paper is drawn from a larger study of Ottoman provincial fiscal administration and paperwork, Linda T. Darling, "Investigating the Fiscal Administration of the Arab Provinces after the Ottoman Conquest of 1516," in The Mamluk-Ottoman Transition: Continuity and Change in Egypt and Bilad al-Sham in the Sixteenth Century, ed. Stephan Conermann and Gül Şen (Göttingen: V\&R, Bonn University Press, 2016), 147-76; here see 158.

4 Muhammad Adnan Bakhit, The Ottoman Province of Damascus in the Sixteenth Century (Beirut: Librairie du Liban, 1982); Enver Çakar, XVI. Yüzyılda Haleb Sancağı (1516-1566) (Elazığ: Firat Üniversitesi Basımevi, 2003); Amnon Cohen, Jewish Life under Islam: Jerusalem in the Sixteenth Century (Cambridge: Harvard University Press, 1984); Amnon Cohen, Economic Life in Ottoman Jerusalem (Cambridge: Cambridge University Press, 1989); Heghnar Zeitlian Watenpaugh, The Image of an Ottoman City: Imperial Architecture and Urban Experience in Aleppo in the 16th and 17th Centuries (Leiden: Brill, 2004).

5 Linda T. Darling, "From Border Province to Imperial Hub: The Geopolitical Shift of Syria from Mamluk to Ottoman Rule," in The Mamluk-Ottoman Transition: Continuity and Change in Egypt and Bilad al-Sham in the Sixteenth Century, Volume II, ed. Stephan Conermann and Gül Şen (Göttingen: V\&R, Bonn University Press, forthcoming), summarizing the existing scholarship on post-conquest Syria. 
Şam, Haleb, and Trablus were mentioned mainly to note appointments and dismissals or to refer to offices formerly held in those provinces. ${ }^{6}$ The mübimme registers reflect the same priorities: orders for official appointments and dismissals significantly outnumber those on resource extraction, and when it came to resources, men were more important than money, at least in the sixteenth century.

\section{MONEY}

Since the best-known aspect of provincial administration is tax collection, let us begin there. Taxation orders in the mubimme registers do not address the collection of revenue directly from the taxpayers; for that we need other sources, such as kadi sicilleri. ${ }^{7}$ Most collection issues in the mühimme registers relate to the deposit of funds in the empire's provincial and central treasuries. These orders frequently commanded officials to obtain revenues from tax collectors who had not yet deposited the money they had either collected and not remitted, or were unable to collect. For example, an entry states that the kadıs (judges) of Trablus and Sermin had been ordered to inspect the accounts of the mültezim of a tax farm, but nothing had been heard from them; the order commanded the governor to investigate this affair in person, inspect the account registers, and send the registers to the Porte. ${ }^{8}$ In another case, the villages of the sultanic has in Sayda and Beirut had their silk taxes cancelled and replaced with the deymos (tithe), a widespread tax in Anatolia; however, the surveyor reported that the Syrians refused to pay this unfamiliar tax, so the deymos was cancelled and the silk tax restored. ${ }^{9}$ It was important for the treasury to receive what was due, from both taxpayers and tax collectors, so officials were required to mediate between the treasury and the taxpayers.

Other orders raise problems that occurred less frequently. One was discrepancies between the amounts that officials were to collect and the capacity of the taxpayers to pay. It was a constant problem to keep track of taxpayers and their conditions. An example is the complaint from Trablus that in some 80 villages the population had left the area; the order in the register commanded the governor to find out the reason for their departure, how long ago it had occurred, and where

6 Linda T. Darling, “The Syrian Provinces in Ottoman Eyes: Three Historians' Representations of Bilad al-Sham," ARAM: The Mamluks and the Early Ottoman Period in Bilad al-Sham: History and Archaeology 9-10 (1997-1998): 348-52.

7 The vexed issue of the marriage tax does not appear in these registers, but in the court records it was this tax that caused the most distress; see Abdul-Karim Rafeq, "Relations between the Syrian 'Ulama' and the Ottoman State in the Eighteenth Century," Oriente Moderno 79 (1999): 67-95.

8 Mübimme 3, \#1209; Darling, "Investigating," 159. On the punishment of a tax farmer who had not turned in his receipts see Halil Sahillioğlu, "Bir Mültezim Zimem Defterine göre XV. Yüzyll Sonunda Osmanlı Darphane Mukataaları," Istanbul Üniversitesi İktisat Fakültesi Mecmuası 23 (1962-3): 145-218.

9 Mühimme 7,\#2684. 
they had gone. ${ }^{10}$ In a case in Safed, a tax collector reported that the avariz (occasional taxes) could not be collected from four neighborhoods because the population had decreased and the remaining inhabitants could not afford the assessed sum. ${ }^{11}$ Another reason for non-payment was the incorrect recording of taxpayers and taxes; for example, villagers and townspeople complained about the fact that although they had an agreement to pay their cizye in a lump sum or maktu', recent survey registers assessed them as separate individuals. ${ }^{12}$ Troubled conditions also inhibited smooth revenue collection; the kad of Baalbek reported in 1571 that he could not collect taxes in the region between Jerusalem and Trablus because the inhabitants were feuding, killing each other and stealing their money. ${ }^{13}$ The government firmly demanded the revenue due, but it also tried to reconcile disaffected taxpayers and control misbehaving officials.

One of the very important affairs, judging by how often it appeared, was oppression of the reaya by tax collectors. It was significant because it struck not only at the sultan's budget but at the legitimacy of his rule, since he and his officials were responsible for providing justice to their subjects. ${ }^{14}$ The existence of these complaints in registers from the height of Süleyman's reign suggests that such oppression was neither a product nor a cause of the empire's decline. Officials and tax collectors had many opportunities to commit oppression, and it is remarkable how often they were uncovered and punished. Offending officials in these registers include the sancakbey of Safed, who took personal possession of all income sources not recorded in the tax registers; subaşıs who entered serbest has lands for exploitative reasons; translators and Samaritan scribes who worked with the subaşı; the emin of the sultan's has in Haleb; the emin of Sermin; the emin of Kisrawan with the nephew of the Beiruti zaim Qaytbay; the mütevelli of the soup kitchen of Jerusalem; and the naib of the Hanbali kadr of Damascus. ${ }^{15}$ The sultan had to entrust distant provinces to his officials, but he was harsh to those who proved untrustworthy.

10 Mübimme 7, \#420; Darling, "Investigating the Fiscal Administration," 160.

11 Mühimme 6,\#78.

12 Mühimme E-12321,\#547,\#548.

13 Mühimme 12, \#821; isyan ve tuğyanlarında musırr olan müfsidler. For another one like this, see Mühimme 3, \#1395; Darling, "Investigating," 160-61.

14 Linda T. Darling, A History of Social Justice and Political Power in the Middle East: The Circle of Justice from Mesopotamia to Globalization (London: Routledge Press, 2013; Darling, "Investigating the Fiscal Administration," 161.

15 For the sancakbey, Mübimme E-12321, \#227, \#484, \#502; the subaşıs, Mübimme 3, \#355, Mübimme 5, \#1039, Mübimme 7, \#1663, Mühimme 12, \#917; the translators, Mübimme 3, \#1198; the Samaritans, Mühimme 5, \#470, Mühimme 7, \#1537; the emin of the sultan's has, Mühimme E-12321, \#471; the emin of Sermin, Mühimme 5, \#721; the emin of Kisrawan and Qaytbay, Mühimm 6e,\#732,\#1194; Mübimm 12e,\#911; the mütevelli, Mübimme 5, \#1017; the Hanbali naib, Mübimme 7, \#2087; Darling, "Investigating," 162. 
One case of oppression is worth recounting in more detail for what it reveals about provincial administration and its relationship to the subject population. ${ }^{16}$ The governor of Şam, Lala Mustafa Paşa, was appointed to lead the Ottoman campaign to Yemen in 1568, but he only went as far as Egypt. After he spent eight or nine months vacillating in Cairo, the sultan recalled him. On his return to Şam, the reay a petitioned against him, stating that he had taken their properties and those of the evkaf and had committed oppression. The Porte ordered a general inspection of the province and of the complaints against Mustafa Paşa. Officials had to re-survey the province, collect the revenues of the governor's has, and investigate Mustafa's financial dealings. The edict warned the judges not to allow witnesses to withdraw from the case on the pretext that they had either retired or been reconciled to the former governor. ${ }^{17}$ The government clearly wanted Lala Mustafa to be convicted and the problems in provincial finance that he had created to be resolved. Subsequent register entries concern remedies for the injustices uncovered by the investigation. ${ }^{18}$ Several entries addressed new issues arising from the survey. ${ }^{19}$ The government worked to ensure not only that it received its funds but that the population had no cause for complaint. The central finance registers present a fuller picture of provincial finances, but the mühimmes, like court records, bring this picture alive, showing how the system worked and how central and provincial officials negotiated with each other and the subjects to resolve problems of resource extraction.

The disbursement of money from the provincial treasury was another important affair. Normally each province paid its own expenses out of its tax receipts, which can be tracked through finance summaries sent to the Porte. ${ }^{20}$ Entries in the mühimme registers were only made when something went wrong, as when two fortresses on the pilgrimage road in Syria failed to receive the salaries for their garrisons and notified the Porte. ${ }^{21}$ The provincial treasury paid for expenses that benefited the state, but also for expenses that benefited the people of the province. Most entries on expenditures concerned the purchase of supplies or the repair of fortifications, such as purchases of gunpowder and repairs to the Payas fortress in

16 Mühimme 7, \#1959, \#960, \#1965, \#1979, \#2011, \#2012, \#2013, \#2014, \#2045, \#2198, and \#2286 all concern this case, summarized from Darling, "Investigating," 163.

17 Mübimme 7, \#2034, \#2035.

18 Mühimme 7, \#2036, \#2038, \#2039,\#2044,\#2046.

19 Mühimme 7, \#2256, \#2267, \#2512,\#2521 (this entry ended the investigation).

20 Darling, "Investigating the Fiscal Administration," 163-64. On these summaries see Halil Sahillioğlu, "Osmanlı İdaresinde Kıbrıs'ın İlk Yılı Bütçesi," Belgeler 4.7/8 (1967): 1-33; idem, "Yemen' in 1599-1600 Yilı Bütçesi," in Yusuf Hikmet Bayur'a Armağan (Ankara: Türk Tarih Kurumu Basımevi, 1985), 287-319; Linda T. Darling, "Ottoman Provincial Treasuries: The Case of Syria," Mélanges Halil Sabillioğlu, Arab Historical Review for Ottoman Studies 15-16 (1997): 103-9.

21 Mühimme 7, \#552. 
Aleppo province, but revenues were also spent on a bathhouse in Hama owned by the state and a cistern in Aclun. ${ }^{22}$ Such expenditures were reported more fully in the financial summaries, but the mühimme entries detail the difficulties they caused and the responsibility for handling them. In the case of repairs, the mübimmes indicate the use of local labor and the resulting wage payments or tax exemptions.

A tricky aspect of money-handling was the transfer of funds to the imperial treasury or to other treasures and enterprises. These fund transfers were made in bullion, heavily guarded against the risks and dangers of carrying cash over roads infested with robbers, tribesmen, and rebels. The mübimme registers show transfers from the treasuries of Şam, Haleb and Egypt to the central treasury, which distributed surpluses from wealthy provinces to poorer ones. ${ }^{23}$ They also show transfers from the treasury of Haleb to the Ottoman forces at Basra, Baghdad, Erzurum, Egypt, and Yemen; ${ }^{24}$ and from the treasury of Şam to Medina for the salaries of Qur'an readers and to Hims for fortifications on the pilgrimage road..$^{25}$ These entries highlight the specialization of the Haleb treasury on military affairs and of Şam's treasury on religious affairs. They also show how the government transported and protected its financial resources without modern means of communication and transportation.

\section{MEN}

A major aspect of resource extraction dealt with the military. Judging by the descriptions of Syria in the Ottoman chronicles, the recruitment of men was even more important than the collection of taxes. Numerous studies have been made of the great families of Syria, but scholars have paid little attention to lower-level military forces. ${ }^{26}$ The replacement of the Mamluk system by the Ottomans' diversified military groups significantly altered military recruitment in Syria. In the midsixteenth century, some of Syria's troops came from the empire's central regions, but

22 For gunpowder, Mühimme 3, \#785; Mühimme 7, \#2091; fortress repairs, Mühimme 7, \#372, \#1375, \#1429, \#2272; bathhouse, Mühimme 3, \#794; cistern, Mühimme 7, \#2317, \#2588; other repairs, Mühimme 12,\#113,\#413,\#431, \#978.

23 For Şam: Mühimme 7, \#2387, profits on evkaf; Mühimme 12, \#12,\#359, avarız; Haleb: Mühimme 3, \#377, \#378; Egypt: Mühimme 3, \#547, \#548, Mübimme 7, \#1438; Darling, "Investigating," 164.

24 For Basra, Mühimme 3, \#765, \#766; Baghdad, Mühimme 5, \#1966, 1968; Erzurum, Mühimme 3, \#531, \#739, and Mühimme 6, \#436, \#532, \#533; for Egypt, Mühimm 7e, \#2269; Yemen, Mübimme 7, \#1253, \#1254. Mühimme 7, \#1248, specified that the Damascus treasury did not have funds to send to Yemen.

25 For Medina, Mühimme 7, \#401; Hims, Mühimme 12, \#552.

26 Darling, "Investigating," 165-66. See Kamal S. Salibi, The Modern History of Lebanon (London: Weidenfeld and Nicolson, 1965; Delmar, NY: Caravan Books, 1993); Abdul-Rahim AbuHusayn, Provincial Leaderships in Syria, 1575-1650 (Beirut: American University of Beirut, 1985). 
a large number were recruited locally. The timar-holding cavalry included not only sons of previous timar-holders but also sons of local elites, even Mamluks, as well as Janissaries and men from other military forces. ${ }^{27}$ The timars of the Syrian provinces were surveyed several times in the sixteenth century. ${ }^{28}$ In the late $1550 \mathrm{~s}$, the problems reported in the mühimmes were receiving timars made out of ruined or unsurveyed land, or having timars taken away for reasons including absence from service and false documentation. ${ }^{29}$

Another of Syria's important military groups was the Janissaries, stationed in Damascus and throughout the province. Their primary function was as a mobile fighting force; thus, the Porte mobilized 1,000 Janissaries of Damascus to go with the governor and a force of cavalry and volunteers on the campaign to Yemen in $1568 .^{30}$ In 1571 it sent Damascus Janissaries to Cyprus for its conquest, although the initial orders to the governor of Şam only commanded grain for the invading troops. ${ }^{31}$ Janissaries from Şam were also sent to Van, Bitlis, Safed, and Aclun, and they transported waqf revenues to Istanbul and garrisoned fortresses on the pilgrimage road..$^{32}$ Multiple orders insisting on the appointment of men from Rumeli and Anatolia rather than Arabs and Kurds inform us that Arabs and Kurds were entering the corps, contrary to the wishes of the central government. ${ }^{33}$ Most Janissary duties do not appear as orders in the mühimme registers, since the provincial governor commanded them in person, but there are exceptions, such as orders to

$27 \quad$ For an empire-wide analysis of the icmal defterleri in terms of the number of timars in the $16^{\text {th }}$ and $17^{\text {th }}$ centuries and the identities of their holders, see Linda T. Darling, "Nasîhatnâmeler, $\dot{I}_{c m a l}$ Defterleri, and the Ottoman Timar-Holding Elite in the Late Sixteenth Century," Osmanl Araştırmaları 43 (2013): 193-226; eadem, "Nasîhatnâmeler, Ícmal Defterleri, and the Ottoman Timar-Holding Elite in the Late Sixteenth Century: Part II, Including the Seventeenth Century," Osmanl Araştırmaları 45 (2015): 13-35.

28 Bakhit, The Ottoman Province of Damascus, 297-98; he did not attempt to track the composition of the military forces. See also Dror Ze'evi, An Ottoman Century: The District of Jerusalem in the 1600s (Albany: State University of New York Press, 1996).

29 For the Syrian provinces see Mübimme 3, \#397, \#756, \# 1094, \#1398; Mübimme 7, \#363, \#2085.

30 The following is summarized from Darling, "Investigating," 166-68. See Mühimme 7, \#614, and many other orders in that register. On the mobilization see Caesar E. Farah, "Organizing for the Second Conquest of Yemen," in X. Türk Tarih Kongresi, 22-26 Eylül 1986: Kongreye Sunulan Bildiriler, 6 vols. (Ankara: Türk Tarih Kurumu, 1990-94), 4: 1457-72; Linda T. Darling, "The Janissaries of Damascus in the Sixteenth Century, or, How Conquering a Province Changed the Ottoman Empire," Otto Spies Memorial Series, v. 6 (Bonn: V\&R Press, 2019); J. Richard Blackburn, "The Collapse of Ottoman Authority in Yemen, 968/1560-976/1568," Die Welt des Islams, n.s. 18 (1979): 119-76.

31 Mübimme 12, for Janissaries: \#508, \#509; other troops, \#195, nüzül: \#c.44, \#397.

32 Mühimme 7, \#791, \#1983; Mühimme 12, \#88, \#423; waqf, Mühimme 7, \#2385, \#2387; pilgrimage road Mübimme 7, \#553,\#2328, \#2621; Mübimme 12, \#597.

33 Mühimme 5, \#991, \#1121; Mübimme 12, \#1008. The reason may simply have been that they knew neither Turkish nor the Balkan languages spoken by many of the Janissaries. 
collect the revenues of the imperial imaret in Damascus and to help with a tahrir. ${ }^{34}$ Some entries mention Damascus Janissaries serving the provincial treasury of Haleb. ${ }^{35}$ Through these registers we see how the empire's military manpower implemented fiscal administration and observe their contributions not only to the war machine but to the communication, transportation, fundraising, and policing functions of the state.

\section{ADMINISTRATION}

The registers of outgoing orders also reveal the structures of provincial administration. The opening statements of orders provide the names of the governors, $k a d \imath s$, and defterdars to whom they were addressed. The orders mention the sancakbeys, as well as provincial military and finance officials. We see who was obedient and who was disobedient, and we sometimes learn about their salaries or their households. The names and titles of individuals who received the written orders and delivered them in the provinces provide information about subordinates of governors and great men. For example, orders were handed for delivery to Murad, the steward or kethüda of the governor of Haleb; Hasan, the steward of the governor of Şam; Hurrem, the steward of the defterdar of Haleb; and Derviş, the steward of the governor of Egypt. In general, this information shows that one of the responsibilities of a kethüda was to present letters and petitions to the Porte in person and return the answers to their employers. ${ }^{36}$ Infrequently mentioned in the orders were the çavuşes or messengers who carried petitions and letters to Istanbul and back. Çavuşes were mostly recruited by the same means as Janissaries, through the devşirme, and one reason for the growth in numbers of "Janissaries" that Ottoman advice writers described as corruption may have been the empire's growing demand for messengers and agents as the empire expanded and the provinces grew more tightly knit together and more closely bound to the center. The expansion of the empire also increased the demand for troops both to campaign and to fill the provincial garrisons along the empire's extended frontiers and in the newly conquered cities. Syria itself had 29 fortresses, all with Janissary contingents; Janissaries were also assigned to the fortresses along the pilgrimage route. ${ }^{37}$

34 Mübimme 7, \#1638, \#2012.

35 Mühimme 7, \#33; Mühimme 3i,\#190.

36 Mübimme 3,\#728, \#1395, \#355, \#547; Darling, “Investigating," 168-69.

37 Bakhit, The Ottoman Province of Damascus, 94-99; Suraiya Faroqhi, Pilgrims and Sultans: The Hajj under the Ottomans, 1517-1683 (London, New York: I.B. Tauris, 1994); Andrew Petersen, The Medieval and Ottoman Hajj Route in Jordan: An Archaeological and Historical Study (Oxford: Oxbow, 2012); BOA.MAD.3723. Other provinces, such as Budin and Misır, also received Janissary contingents. 
A mark of the growing closeness among the empire's different parts was the central administration's dependence on the information in the provincial registers. Entries in the mübimme register of 1544 notified the defterdar of "Arabistan" that the detailed registers of the Şam treasury for the previous year had not reached the Porte, nor had the avariz, mubasebe, and mukataa registers for Arabistan and the registers for the Ekrad sancak. ${ }^{38}$ The central government needed these registers to make up its own accounts of income and expenditures for the year. ${ }^{39} \mathrm{~A}$ few years later, the mütevelli of the Sultan Süleyman evkaf in Şam went off to serve in Egypt without turning in his registers. This became an "important affair" because he left a school unbuilt, reporting that construction of the water fountain had used up all the money; stone, lead, and other building materials had been ordered but only partially used and possibly not paid for. The entry commanded the governor and $k a d z$ to confront the mütevelli in person, obtain his registers, investigate the problems he left, and notify the Porte of their findings. ${ }^{40}$ Governing the empire depended more and more on receiving reports and registers from the provinces. Istanbul could conquer on its own initiative, but it could only govern on the basis of reports and petitions from the provinces. ${ }^{41}$ Submitting a petition was thus a political act, and the same could be said for submitting a register. Their absence represented a flaw in the state of peace and a problem for administrators. Orders reiterated that submitting one's registers was one of the "important affairs" of the empire; archives then represent both the act and the evidence of obedience.

\section{CONCLUSION}

The story told of Ottoman rule in the Arab provinces has usually been one of oppression and extortion, but a more detailed look at provincial resources in the mühimme registers modifies this picture by revealing not only the problems faced by the new administrators but the efforts and negotiations employed in addressing them, not only the taxes raised from the population but the infrastructure and accomplishments they funded, not only oppression by officials but their pursuit

38 Mühimme E-12321,\#390, \#520,\#546, \#336; Darling, “Investigating," 169-70.

39 On accounting registers see Ömer Lütfi Barkan, “H. 933-934 (M. 1527-1528) Malî Yılına ait bir Bütçe Örneği," İstanbul Üniversitesi İktisat Fakültesi Mecmuası 15 (1953/54): 251-329; idem, “954-955 (1547-1548) Malî Yılına âit bir Osmanlı Bütçesi," İstanbul Üniversitesi İktisat Fakültesi Mecmuası 19 (1957/58): 219-76; idem, "H. 974-975 (M. 1567-1568) Malî Yılına âit bir Osmanlı Bütçesi," İstanbul Üniversitesi İktisat Fakültesi Mecmuası 19 (1957/58): 277-332; on procedures, Linda T. Darling, Revenue-Raising and Legitimacy: Tax Collection and Finance Administration in the Ottoman Empire, 1560-1660 (Leiden: E. J. Brill, 1996), 213-45.

40 Mühimme 7, \#1643.

41 Linda T. Darling, "The Finance Scribes and Ottoman Politics," in Decision Making in the Ottoman Empire, ed. Caesar E. Farah (Kirksville, MO: Thomas Jefferson University Press and University Press of America, 1993), 89-100; eadem, "Investigating," 173. 
of justice as well. The extensive process of interaction due to Ottoman conquest emerges vividly. Far from a top-down imposition of power, ruling a conquered province was a constant balancing act between the authority and the impotence of the distant state, the impulses to obedience or self-aggrandizement of its officials, and the conquered people's level of tolerance and their ability to intervene in the process. Much of this negotiation took place in the arena of fiscal administration, an ideal site for investigating its procedures and contingencies.

We should not think only of resource extraction, however. Money and materials also came into the province with the Ottoman troops and were employed not only in palaces and fortifications for the elite but fountains, schools, markets, cisterns, and bathhouses for ordinary people, as well as for protecting the pilgrimage. The Ottoman elites sent to govern their new conquests settled in and localized, becoming new and well-connected members of their communities and linking them to a larger imperial society. ${ }^{42}$ The first half of the sixteenth century saw a tightening of the bonds between provinces and center that is reflected in the mühimme defterleri. Through its demands for provincial registers and reports, inspections of officials, and appointments of agents, the government sought to centralize provincial affairs on Istanbul, if that word is not too strong, or at least to keep the center informed of conditions in the provinces. In the debate over whether the Ottoman Empire was governed by the sultan's absolute rule or by negotiation, the mübimme registers answer, both. ${ }^{43}$ These registers span the gap between ideology and implementation and allow us to investigate the relationship between absolutism and negotiation in the premodern conditions of the Ottoman Empire.

\section{BIBLIOGRAPHY}

\section{SOURCES}

Başbakanlık Osmanlı Arşivi. Maliyeden Müdevver Defterleri \#3723.

Topkapı Sarayı Arşivi H.951-952 Taribli ve E-12321 Numaralı Mühimme Defteri. Ed. Halil Sahillioğlu. Istanbul: IRCICA, 2002.

3Numaralı MühimmeDefteri(966-968/1558-1560), Özetve Transkripsiyon. Ankara: T.C. Başbakanlık Devlet Arşivleri Genel Müdürlüğü, Osmanlı Arşivi Daire Bakanlığı, 1993.

42 Ze'evi, An Ottoman Century; Darling, "Investigating the Fiscal Administration of the Arab Provinces," 173. In later periods, we know the local elites sponsored commercial and cultural activity; where were their resources invested in the early $16^{\text {th }}$ century?

43 See Karen Barkey, Bandits and Bureaucrats: The Ottoman Route to State Centralization (Ithaca, London: Cornell University Press, 1994), which favors negotiation, and the various reviews and critiques of this book. 
5 Numaralı Mühimme Defteri (973/1565-1566), Özet ve İndeks. Ankara: T.C. Başbakanlık Devlet Arşivleri Genel Müdürlügüu, Osmanlı Arşivi Daire Bakanlığı, 1994.

6 Numaral Mühimme Defteri (972/1564-1565), Özet - Transkripsiyon ve İndeks. Ankara: T.C. Başbakanlık Devlet Arşivleri Genel Müdürlüğü, Osmanlı Arşivi Daire Bakanlığı, 1995.

7Numaralı MübimmeDefteri (975-976/1567-1569), Özet-Transkripsiyon - Indeks. Ankara: T.C. Başbakanlık Devlet Arşivleri Genel Müdürlüğü, Osmanlı Arşivi Daire Bakanlı̆̆ 1998.

12 NumaralıMühimmeDefteri(978-979/1570-1572), Özet-Transkripsiyon ve Indeks. Ankara: T.C. Başbakanlık Devlet Arşivleri Genel Müdürlüğü, Osmanlı Arşivi Daire Bakanlığı, 1998.

\section{STUDIES}

Abu-Husayn, Abdul-Rahim. Provincial Leaderships in Syria, 1575-1650. Beirut: American University of Beirut, 1985.

Barkan, Ömer Lütfi. “H. 933-934 (M. 1527-1528) Malî Yılına ait bir Bütçe Örneği.” İstanbul Üniversitesi İktisat Fakültesi Mecmuasi 15 (1953/54): 251-329.

Barkan, Ömer Lütfi. "954-955 (1547-1548) Malî Yılına âit bir Osmanlı Bütçesi," İstanbul Üniversitesi İktisat Fakültesi Mecmuası 19 (1957/58): 219-76.

Barkan, Ömer Lütfi. "H. 974-975 (M. 1567-1568) Malî Yılına âit bir Osmanlı Bütçesi.” İstanbul Üniversitesi İktisat Fakültesi Mecmuası 19 (1957/58): 277-332.

Bakhit, Muhammad Adnan. The Ottoman Province of Damascus in the Sixteenth Century. Beirut: Librairie du Liban, 1982.

Barkey, Karen. Bandits and Bureaucrats: The Ottoman Route to State Centralization. Ithaca, London: Cornell University Press, 1994.

Blackburn, J. Richard. "The Collapse of Ottoman Authority in Yemen, 968/1560976/1568.” Die Welt des Islams, n.s. 18 (1979): 119-76.

Cohen, Amnon. Economic Life in Ottoman Jerusalem. Cambridge: Cambridge University Press, 1989.

Cohen, Amnon. Jewish Life under Islam: Jerusalem in the Sixteenth Century. Cambridge: Harvard University Press, 1984.

Çakar, Enver. XVI. Yüzyılda Haleb Sancă̆ı (1516-1566). Elazığ: Fırat Üniversitesi Basımevi, 2003.

Darling, Linda T. “The Finance Scribes and Ottoman Politics." In Decision Making in the Ottoman Empire. Ed. Caesar E. Farah, 89-100. Kirksville, MO: Thomas Jefferson University Press and University Press of America, 1993. 
Darling, Linda T. "From Border Province to Imperial Hub: The Geopolitical Shift of Syria from Mamluk to Ottoman Rule." In The Mamluk-Ottoman Transition: Continuity and Change in Egypt and Bilad al-Sham in the Sixteenth Century, Volume II. Ed. Stephan Conermann and Gül Şen Göttingen: V\&R, Bonn University Press, forthcoming.

Darling, Linda T. A History of Social Justice and Political Power in the Middle East: The Circle of Justice from Mesopotamia to Globalization. London: Routledge Press, 2013.

Darling, Linda T. "Investigating the Fiscal Administration of the Arab Provinces after the Ottoman Conquest of 1516." In The Mamluk-Ottoman Transition: Continuity and Change in Egypt and Bilad al-Sham in the Sixteenth Century. Ed. Stephan Conermann and Gūl Şen, 147-76. Göttingen: V\&R unipress, Bonn University Press, 2016.

Darling, Linda T. "The Janissaries of Damascus in the Sixteenth Century, or, How Conquering a Province Changed the Ottoman Empire." Otto Spies Memorial Lecture, Vol. 6. Ed. Stephan Conermann and Gūl Şen. Bonn: $\mathrm{V} \& \mathrm{R}$ unipress, forthcoming.

Darling, Linda T. "Nasîhatnâmeler, Ícmal Defterleri, and the Ottoman TimarHolding Elite in the Late Sixteenth Century." Osmanlı Araştırmaları 43 (2013): 193-226.

Darling, Linda T. "Nasîhatnâmeler, İcmal Defterleri, and the Ottoman TimarHolding Elite in the Late Sixteenth Century: Part II, Including the Seventeenth Century." Osmanl Araştırmaları 45 (2015): 13-35.

Darling, Linda T. "Ottoman Provincial Treasuries: The Case of Syria." Mélanges Halil Sabillioğlu, Arab Historical Review for Ottoman Studies 15-16 (1997): 103-9.

Darling, Linda T. Revenue-Raising and Legitimacy: Tax Collection and Finance Administration in the Ottoman Empire, 1560-1660. Leiden: E. J. Brill, 1996.

Darling, Linda T. "The Syrian Provinces in Ottoman Eyes: Three Historians' Representations of Bilad al-Sham." ARAM: The Mamluks and the Early Ottoman Period in Bilad al-Sham: History and Archaeology 9-10 (19971998): 347-55.

Ebel, Kathryn A. "Representations of the Frontier in Ottoman Town Views of the Sixteenth Century." Imago Mundi 60.1 (2008): 1-22.

Farah, Caesar E. "Organizing for the Second Conquest of Yemen." In X. Türk Tarih Kongresi, 22-26 Eylül 1986: Kongreye Sunulan Bildiriler. 6 vols., 4: $1457-$ 72. Ankara: Türk Tarih Kurumu, 1990-94.

Faroqhi, Suraiya. Pilgrims and Sultans: The Hajj under the Ottomans, 1517-1683. London, New York: I.B. Tauris, 1994. 
Petersen, Andrew. The Medieval and Ottoman Hajj Route in Jordan: An Archaeological and Historical Study. Oxford: Oxbow, 2012.

Rafeq, Abdul-Karim. "Relations between the Syrian 'Ulama' and the Ottoman State in the Eighteenth Century." Oriente Moderno 79 (1999): 67-95.

Sahillioğlu, Halil. "Bir Mültezim Zimem Defterine göre XV. Yüzyll Sonunda Osmanlı Darphane Mukataaları.” İstanbul Üniversitesi İktisat Fakültesi Mecmuasi 23 (1962-3): 145-218.

Sahillioğlu, Halil. “Osmanlı İdaresinde Kıbrıs'in İlk Yılı Bütçesi.” Belgeler 4.7/8 (1967): 1-33.

Sahillioğlu, Halil. "Yemen'in 1599-1600 Yılı Bütçesi." In Yusuf Hikmet Bayur'a Armağan. 287-319. Ankara: Türk Tarih Kurumu Basımevi, 1985.

Salibi, Kamal S. The Modern History of Lebanon. London: Weidenfeld and Nicolson, 1965; rpt. Delmar, NY: Caravan Books, 1993.

Watenpaugh, Heghnar Zeitlian. The Image of an Ottoman City: Imperial Architecture and Urban Experience in Aleppo in the 16th and 17th Centuries. Leiden: Brill, 2004.

Ze'evi, Dror. An Ottoman Century: The District of Jerusalem in the 1600s. Albany: State University of New York Press, 1996. 